\title{
6 From acceptability and acceptance to active behavioral support
}

\author{
Engaging the general public in the transition \\ of the electric energy system in Finland
}

\author{
Matti Kojo, Ilkka Ruostetsaari, Jussi Valta, \\ Pami Aalto and Pertti Järventausta
}

\section{Introduction}

Transition of the electric energy system is a multifaceted sociotechnical challenge. Transition requires "smart" technology and infrastructure, i.e., hardware including metering and photovoltaic cells and software for managing and optimizing millions of assets, while the planning and deployment of transition also entail socio-political dimensions. For instance, renewable energy production needs a policy supported by citizens, siting of wind farms needs to be accepted locally and residents and consumers need to be more flexible in their electricity consumption, for example through home automation. In this chapter, we focus on the social acceptance and acceptability of transition of the electric energy system. Transition of the electric energy system is understood as progress towards future sustainable energy systems, involving more decentralized assets with smart management.

Citizens and consumers are deemed to have a more central role in the future electric energy system which will be more automated or "smarter" and decentralized. This role has been embedded in the EU regulation. Recently EU Directive (2019/944) defined Citizen Energy Communities and more generally emphasized the role of the customer, while the Renewable Energy Directive (2018/2001) defined "prosumers," i.e., individuals and communities entitled to generate, consume, store or sell electricity from renewable energy sources (Antoni and Rodi in this book). The social dimension of the transition is also noted in the national energy policies. For example, the Finnish climate and energy strategy states that "while technological progress may enable energy savings without the consumers taking on an active role, many of the policies require a new type of agency of the citizens in changing living conditions" (MEAE, 2017, p. 97). These remarks call for studying social acceptance and acceptability of the energy transition.

Acceptance of single technologies, for example wind energy, solar power or power lines has been extensively studied (e.g., Leiren et al., 2020; Sütterlin and Siegrist, 2017; Horbaty et al., 2012; Wolsink, 2012) likewise the use of renewable energy technology (e.g., Kardooni et al., 2016). However, we seek to identify those dimensions of social acceptance and acceptability of the transition of the 


\section{Matti Kojo et al.}

whole electric energy system which are potential bottlenecks demanding more attention in policymaking and which are more receptive to new policies (see also Bolwig et al., 2020). We moreover contribute to the conceptual discussion on social acceptance, acceptability and behavioral support.

The objective is to study social acceptability of transition of the electric energy system in Finland. We ask: which measures of the energy transition are currently socially acceptable in Finland? Which measures and sectors may need reconsideration and public engagement in the future? Finland, a Nordic front runner in low-carbon energy transition is used as an example. According to Sovacool (2017, p. 569) the Nordic countries offer a paradigmatic example with their progressive energy and climate policies, longstanding policy goals, binding climate targets and ambition to become entirely or largely "fossil fuel free" or "carbon neutral." However, the Nordic countries are not uniform. The Finnish energy economy is dominated by biomass and forestry products, Finland is an energy net importer, hosts heavy industry and is building new nuclear power units (Sovacool, 2017, p. 569; see Figure 6.1). The major energy utilities, heavy industry and grid operators and their organizations have influenced Finnish climate and energy policies, which have been less reform-oriented (Hildén and Kivimaa, 2020, p. 3, 16). Institutional arrangements have remained relatively stable and decision-making in energy policy has been in the hands of a closed, relatively unchanged "energy elite" for decades (Kainiemi et al., 2020, p. 3). The approach of Finnish energy governance has relied less on individuals' and consumers' activities than has Denmark, for example, making Finland an interesting case study in terms of social acceptance. Already today some of the Finnish energy expert stakeholders concur in assigning a more active role to consumers (Toivanen et al., 2017). Moreover, a green transition coalition although not internally uniform - has been formed, affecting Finnish climate and energy policy (Haukkala, 2018; Kainiemi et al., 2020; Varho et al., 2016).

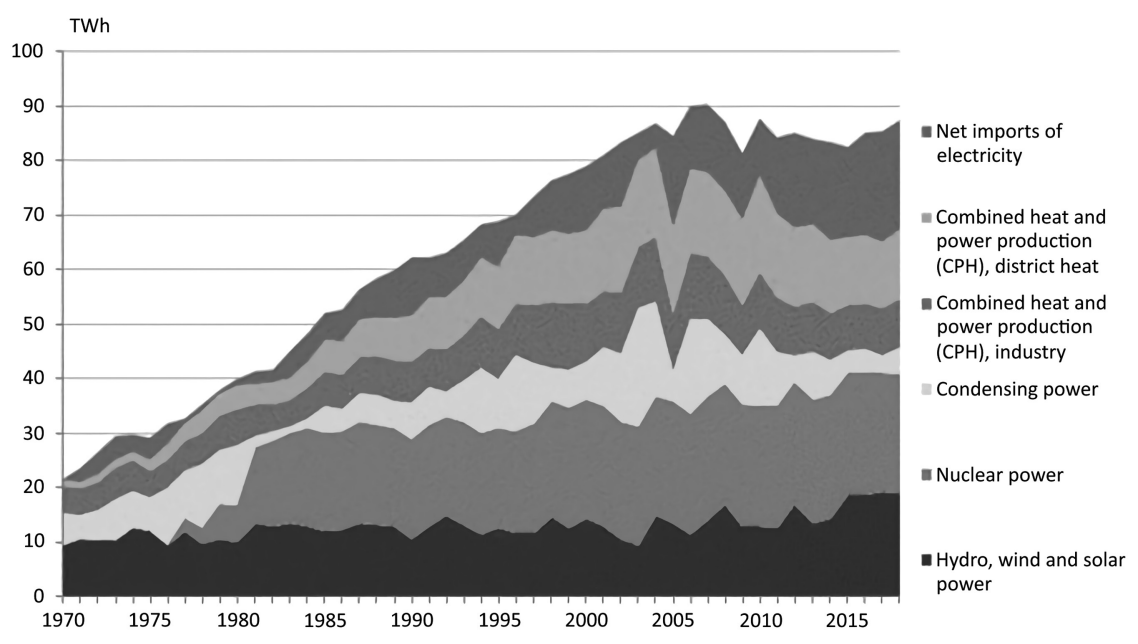

Figure 6.1 Electricity supply in Finland in 1970-2018 ( Source: Statistics Finland, 2019). 
However, the current prosumer base is rather thin in Finland, although the Energy Authority (2020) recently reported increasing small-scale electricity generation among households. At the end of 2019, solar photovoltaic generation capacity connected to the electricity grid was approximately 198 megawatts and $20 \mathrm{MW}$ off-grid especially in holiday homes. Capacity increased annually by $64 \%$.

In order to affect transition, the prosumer base should be more substantial. According to Kotilainen et al. (2021) prosumer base growth would bring benefits such as a greater number of renewable energy sources and distributed generation and new business opportunities. The main concerns related to mass prosumerism included a perceived threat of out-of-control microgrids that could destabilize the whole electricity system, business challenges to the existing energy sector companies and a potential off-grid movement led by consumers. ${ }^{1}$

In terms of technical conditions for transition, the Finnish electric energy system has some advantages, among them smart metering equipment already installed in almost every household, high share of renewable energy production, ${ }^{2}$ distribution automation and IT solutions for network management and an efficient open electricity market as part of the Nordic electricity market (Järventausta et al., 2011). One essential source of empowerment of customers' energy transition participation is the penetration of smart meters in Finland. At present over $99 \%$ of customers have a smart meter measuring hourly energy consumption, registering ( $>3 \mathrm{~min}$ ) interruptions and enabling load control facilities under the electricity market legislation (Pöyry Management Consulting, 2017, p. 15). The authority is currently determining the functionality of the next generation of smart meters providing even more accurate and real-time data measurements for the business process and local use (Pahkala et al., 2018). Smart metering can, for example, improve competition in the electricity market by facilitating flexible change of energy retailers and enabling dynamic tariffs. The ample data offered by smart meters can also be used to develop new functions for Smart Grids, for example in low voltage network management and load modeling for more accurate network state estimation and planning purposes (Järventausta, 2015).

From the legislative perspective, for instance, the Clean Energy Package (European Union, 2019a) is not expected to result in extensive legislative reform in Finland, but some issues such as energy communities in the regulatory framework, encouragement of prosumer participation in demand flexibility and acceleration of aggregator services are considered to require either legislative "fine-tuning" or thorough revision (Penttinen et al., 2020).

Finally, it should be remembered that because many people in Finland live in housing associations, these are crucial in decision-making on energy transition and commitment to sustainability at the household level (see Laakso and Lukkarinen in this book).

The structure of the chapter is as follows. In section two, the framework of the study based on the concepts of social acceptance and acceptability is introduced. Section three focuses on method and survey data. Section four has three sub-sections, namely production, network and consumption, which compose the 


\section{Matti Kojo et al.}

electric energy system. Results noting challenges in each sector with all dimensions of social acceptability are discussed in section five.

\section{Framework: in search of active support from the general public}

Public, social acceptance and acceptability have been actively discussed in relation to different (controversial) energy technologies but also energy transition in general (e.g., Järvelä et al., 2020; de Wildt et al., 2019; Lennon et al., 2019; Batel, 2018; Krick, 2018; Devine-Wright et al., 2017; Sütterlin and Siegrist, 2017; Upham et al., 2015; Kasperson and Ram, 2013; Wolsink, 2012; van Alphen et al., 2007). One reason for this interest is the lack of progress in the commercialization of technologies and strategic search for a social mandate for projects. For example, Gupta et al. (2012) note that public opposition to controversial technologies has frequently resulted in negative consequences for their commercialization. These negative consequences have served to emphasize the importance of public acceptance in the strategic development, application and commercialization of technologies. (Gupta et al., 2012, p. 783.)

Lack of progress and public opposition can also be seen to result from biased approaches applied in implementation. Acceptability therefore applies not only to the technology as such but also to its design, planning, implementation and communication (Järvelä et al., 2020). Participatory approaches and understanding of technologies as sociotechnical combinations have emphasized the role of public and stakeholder engagement in planning and decisionmaking (see e.g., Bergmans et al., 2014; Geels et al., 2016). However, energy transition engagement needs the public to assume a more active and personal role than merely involvement in planning and decision-making, for instance, the acquisition and use of new technology in households, such as heat pumps and solar panels or a decision to change behavior when reducing or giving up private motoring. Therefore, from the perspective of implementing an energy transition it is important to understand when mere attitudinal acceptability and acceptance (i.e., absence of opposition) is enough and when wider support and readiness for change in behavior are also required (Upham et al., 2015; Dreyer et al., 2017; Järvelä et al., 2020). Here we rely on the two-dimensional differentiation of acceptability, acceptance and support by Dreyer et al. (2017) where support, for instance willingness among end-users to adopt an energy application, embodies the behavioral dimension as opposed to mere attitudinal acceptance (see Figure 6.2). The long-term realization of such active support would be an important asset for the implementation of the energy transition, for example in demand response flexibility.

Wüstenhagen, Wolsink and Bürer (2007, p. 2684) note that social acceptance is mentioned frequently in the literature but without clear definitions. The terms (public) acceptance and (public) acceptability have also been used frequently and extensively in relation to technology issues, but they have not been rigorously defined or are used interchangeably. Wüstenhagen, Wolsink and Bürer (2007) contribute to the discussion by distinguishing three dimensions of social 


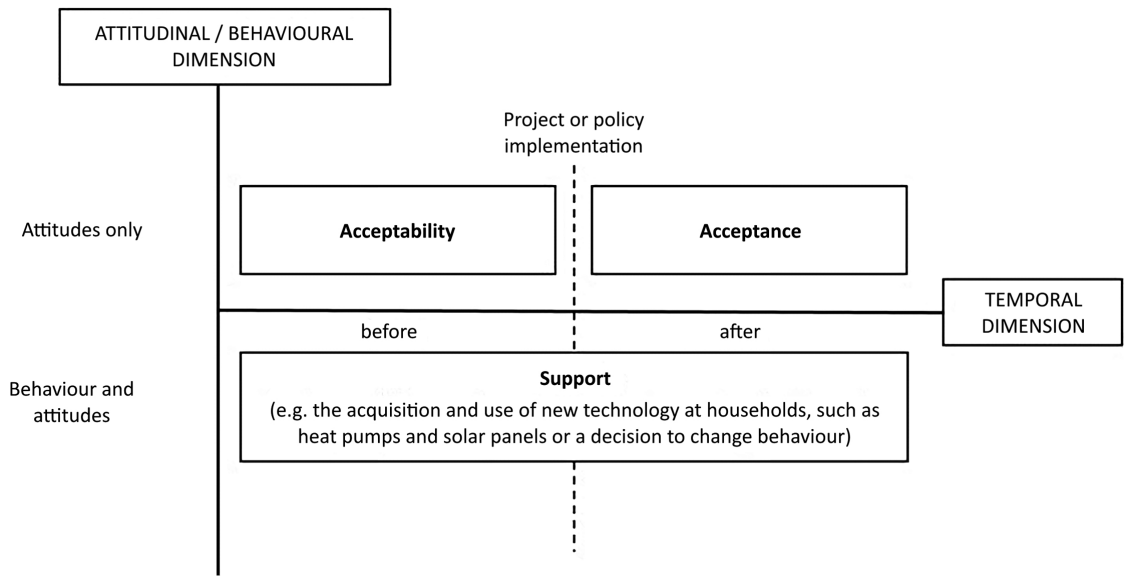

Figure 6.2 Two-dimensional differentiation of acceptability, acceptance and support (Based on Dreyer et al., 2017).

acceptance based on the analysis of renewable energy innovations. The dimensions included in their conceptualization are as follows:

- Socio-political acceptance, which is the broadest, most general level. It refers to acceptance of technologies and policies by the public, the key stakeholders and policymakers;

- Community acceptance, which refers to the specific acceptance of siting decisions and projects by local stakeholders, particularly residents and local authorities. The focus is on procedural and distributional justice and trust;

- Market acceptance, which, in a wider sense, refers not only to consumers, but also to investors and the intra-firm situation. The term has been equated with willingness to pay (Järvelä et al., 2020, p. 6).

Wolsink (2012) also makes a distinction between public and social acceptance. Wolsink (2012, p. 1785) defines public acceptance as "the degree to which a phenomenon is taken by the general public, the degree to which the phenomenon is liked by individual citizens" whereas social acceptance is understood as "the degree of which a phenomenon (e.g., wind power implementation) is taken by relevant social actors, based on the degree how the phenomenon is (dis-)liked by these actors." In Wüstenhagen, Wolsink and Bürer's (2007) definition different dimensions of acceptance refer to different publics, namely stakeholders.

Another distinction in the discussion is made between terms acceptance and acceptability. Wolfe, Bjornstad, Russell and Kerchner discuss technology acceptability and technology acceptance. They define acceptability as "the willingness to consider the technology in question as a viable alternative" (Wolfe et al., 2002, p. 140) whereas acceptance refers to the decision to deploy, i.e., "the 


\section{Matti Kojo et al.}

formal decision to implement the proposal" (Flynn, 2007, p. 16). As evidence of acceptability Wolfe et al. (2002) see willingness to negotiate about a technology, which may be conditioned by various concerns. Sütterlin and Siegrist (2017) also note excessively positive imageries of new technology and therefore call for a more reliable acceptance rating taking account of drawbacks (concerns) in technology. They state that assessment on the basis of an opinion poll is too abstract as respondents do not think about drawbacks when contemplating from a general perspective. On the other hand, a survey is a cost-effective method for gathering information from a large number of respondents.

We define social acceptability as a term subsuming different thematic dimensions (socio-political, community and market) whose priority is subject to constant societal debate and negotiation between the policymakers and other stakeholders including the general public (see e.g., Toivanen et al., 2017). Thus, we adopted the categorization of dimensions from Wüstenhagen, Wolsink and Bürer (2007) but instead of acceptance, which is the term used by Wüstenhagen and colleagues we refer to Wolfe et al. (2002). Moreover, the behavioral dimension in the form of active support is important in the transition to an electric energy system.

Wolfe et al. (2002, p. 140) perceive their approach as a process rather than being outcomes oriented. Acceptability is seen as a continuum, not a dichotomy. Part of the process-like nature of acceptability is that it may vary over time, positively and negatively. Acceptability can therefore be seen as a social process in which actors influence each other through various types of interaction (Huijts et al., 2007, p. 2780).

\section{Method and data}

Our data is based on a citizen survey. Although survey as a method for assessing public acceptance was criticized by Sütterlin and Siegrist (2017), the method is important for building a holistic picture regarding people's opinions on energy transition at the national level. The questionnaire was used to elicit the opinions of people in Finland aged 18 to 75 concerning energy policy. A stratified sampling procedure ensured that the sample covered all socio-demographic groups and geographical regions of Finland, excluding the province of Åland. The survey, including one reminder round, was implemented in August-October 2016. ${ }^{3}$ Although the response rate was relatively low (33.6), this is not unusual for postal/internet surveys. ${ }^{4}$ The large size of the sample $(N=4,000)$ ensured that the data adequately represent the Finnish population at large (Ruostetsaari, 2020).

However, the data deviates in minor respects from the population at large as reported in a detailed loss analysis by Ruostetsaari (2020). The gender distribution of the data corresponds well to the population, but the youngest cohort of 18-29-year-olds is underrepresented, whereas respondents aged 45-59 and 60-75 are clearly overrepresented. Compared to the Finnish population at large, the highly educated were overrepresented, whereas individuals with only basic education were underrepresented. In terms of educational field, people from the engineering and service branches were somewhat underrepresented. Regarding 
occupational positions, lower functionaries were underrepresented, whereas managers and upper functionaries, blue-collar workers and pensioners were somewhat overrepresented. Individuals living in detached houses were clearly overrepresented, and those living in apartment buildings were underrepresented. Also, people living in small municipalities were somewhat overrepresented, while those living in large municipalities were underrepresented. However, the respondents represented the various regions of Finland (provinces) with an even distribution. Due to these minor deviations, it could have been expected that the respondents were more interested than the general population in energy issues. However, this does not appear to have been the case. For instance, $48 \%$ of our survey respondents had never changed their electricity supplier, which is almost the same proportion $(50 \%)$ as that reported by another survey conducted among the general population (TNS Energiabarometri Q1, 2016). Because our data represents the Finnish population at large relatively well, the data was not weighted in our analyses.

There are also some other recent surveys on attitudes to energy policy in Finland. However, these surveys were focused on households' willingness to participate in demand response and energy-saving behaviors (Ruokamo et al., 2018; Ruokamo et al., 2019; Umit et al., 2019). Moreover, Finnish Energy (2019) publishes survey results on Finnish energy attitudes annually.

In this chapter the electric energy system is seen as a combination of production, network and consumption (see Table 6.1). Each element of the electric

Table 6.1 Social acceptability of electric energy system in Finland

\begin{tabular}{|c|c|c|c|}
\hline \multirow[b]{2}{*}{$\begin{array}{l}\text { Dimension of social } \\
\text { acceptance }\end{array}$} & \multicolumn{3}{|c|}{ Components of electric energy system } \\
\hline & Production & Network & Consumption \\
\hline $\begin{array}{l}\text { Socio-political - } \\
\text { acceptance of } \\
\text { technologies } \\
\text { and policies }\end{array}$ & $\begin{array}{l}\text { Finland will shift } \\
\text { to entirely } \\
\text { renewable } \\
\text { energy } \\
\text { production } \\
\text { forms by } 2030 \text {. }\end{array}$ & $\begin{array}{l}\text { I am ready to pay higher } \\
\text { transfer payments } \\
\text { to the distribution } \\
\text { companies than today } \\
\text { if power outages in my } \\
\text { household become less } \\
\text { frequent. }\end{array}$ & $\begin{array}{l}\text { Personal emission } \\
\text { quotas should be } \\
\text { deployed. }\end{array}$ \\
\hline $\begin{array}{l}\text { Community - } \\
\text { acceptance of } \\
\text { siting decisions } \\
\text { and projects }\end{array}$ & $\begin{array}{l}\text { I accept building of } \\
\text { wind power in } \\
\text { the vicinity of } \\
\text { my home. }\end{array}$ & $\begin{array}{l}\text { I am satisfied with the } \\
\text { current reliability of } \\
\text { electricity supply at my } \\
\text { household. }\end{array}$ & $\begin{array}{l}\text { My home } \\
\text { municipality } \\
\text { will be climate } \\
\text { neutral by } 2030 .\end{array}$ \\
\hline $\begin{array}{l}\text { Market - } \\
\text { the process } \\
\text { of market } \\
\text { adoption of an } \\
\text { innovation }\end{array}$ & $\begin{array}{l}\text { I am ready to shift } \\
\text { to dynamic } \\
\text { pricing in which } \\
\text { my electricity } \\
\text { bill is based on } \\
\text { hourly market } \\
\text { prices. }\end{array}$ & $\begin{array}{l}\text { I am ready to hand over } \\
\text { the control of some } \\
\text { electricity intensive } \\
\text { equipment to the } \\
\text { service provider against } \\
\text { reimbursement. }\end{array}$ & $\begin{array}{l}\text { I prefer using } \\
\text { renewable energy } \\
\text { in my household. }\end{array}$ \\
\hline
\end{tabular}




\section{Matti Kojo et al.}

energy system is assessed from the viewpoint of three dimensions of social acceptability (socio-political, community and market). For example, on the socio-political dimension of production, respondents were asked to react to the statement "Finland will shift to entirely renewable energy production forms by 2030." The five response options were as follows: I totally agree, I somewhat agree, I somewhat disagree, I totally disagree and I cannot say. In order to ascertain the differences between various population groups we focus on themes for which there is a statistical dependence (Pearson chi-square $<0.05$ ) between background variables and the statements. The effect of background variables on the endorsement of statements was tested statistically ( $\chi 2$ test) but in the interests of a concise presentation the results of tests are not presented in terms of every single background variable and statement. Comparison between various population groups helps to create an overall picture of people's opinions on energy transition and their own role in it. Although Finnish energy governance has not been based on the activity of individuals and consumers, it is vital to explore this potential as well, as the development of decentralized energy system and forthcoming emission reduction targets will necessitate the introduction of new measures calling for more active energy citizenship (Kotilainen, 2020; Ruostetsaari, 2020).

\section{Results}

\section{Socio-political dimension}

As regards the socio-political dimension, the statement concerning production was as follows: "Finland will shift to entirely renewable energy production forms by 2030 ." and $42 \%$ of all respondents agreed with the statement whereas $46 \%$ disagreed (see Figure 6.3). Men were more opposed to this aim than women as only $38 \%$ of men agreed and more than half (55\%) disagreed. In terms of age, the respondents aged 18 to 29 were most frequently in favor of the shift towards renewables (50\% of the age group agreed) whereas the age group from 45 to 59 was most skeptical towards the shift to renewables (51\% disagreed). Regarding educational background, those with university education most frequently supported the shift to renewables. However, the most enthusiastic supporters of the shift were those with no vocational education at all as $16 \%$ of them totally agreed with the statement compared to $10 \%$ of the respondents with university education, who were the second most enthusiastic supporters.

In terms of field of vocational education, the respondents with educational background in the humanities or arts were most frequently in favor of renewables (62\% agreed), likewise the majority of respondents with education in pedagogics $(52 \%)$ and social sciences $(50 \%)$ whereas, for example among those with education in engineering 36\% agreed. Respondents with education in natural sciences disagreed (51\%) most frequently. Political affiliation was also related to respondents' opinions. ${ }^{5}$ Supporters of the Greens (75\%) and the Left Alliance $(54 \%)$ most frequently agreed with the shift towards renewables. A clear majority of the supporters of the right-wing populist political party, the Finns Party (61\%) 


\section{Socio-political - Production}

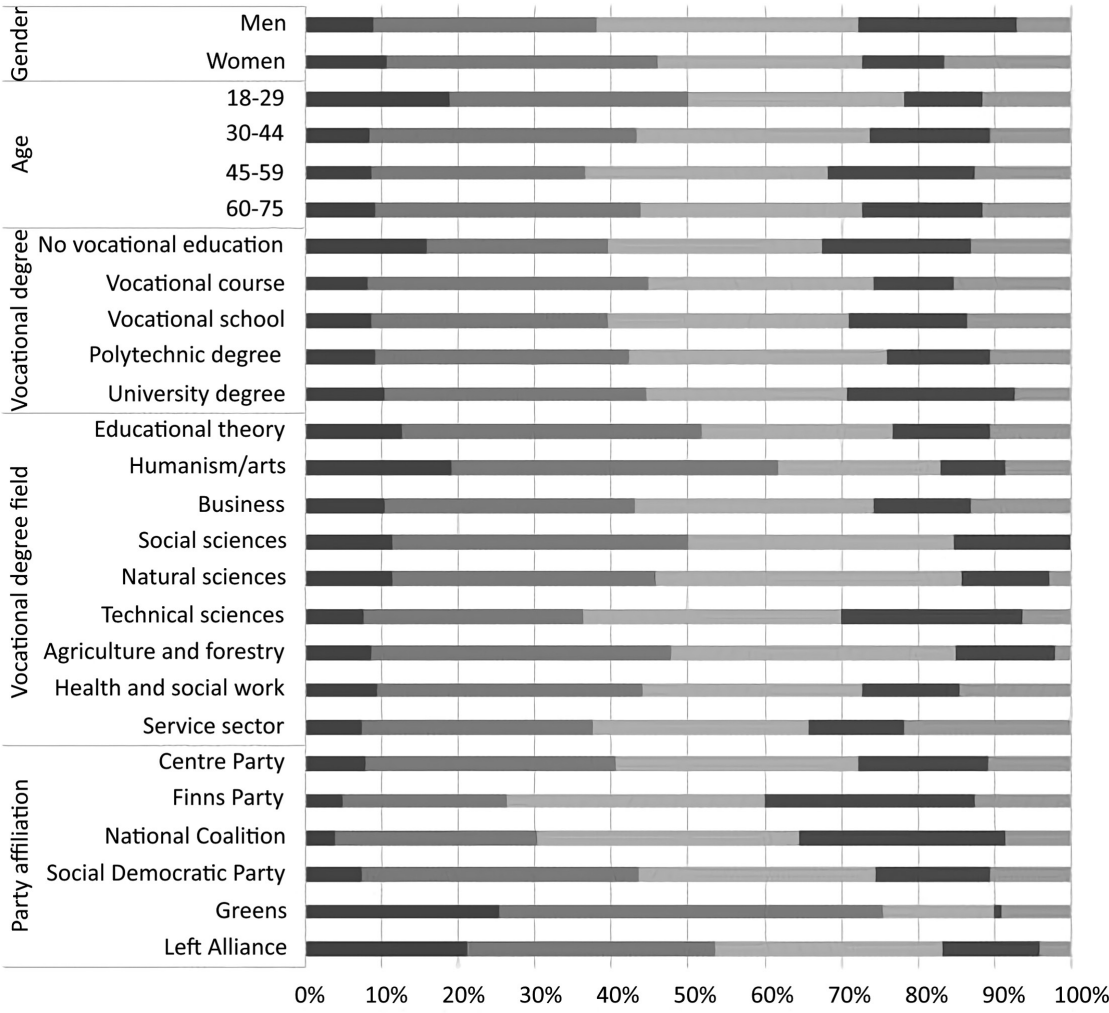

$\square$ Totally agree $\square$ Somewhat agree $\square$ Somewhat disagree $\square$ Totally disagree $\square$ I can't say

Figure 6.3 Respondents' attitudes on the statement "Finland will shift to entirely renewable energy production forms by 2030."

and the National Coalition Party (the conservatives) (61\%) disagreed with the statement. Almost one out of three of them was totally against them.

As regards the socio-political dimension, the statement concerning the network reads as follows: "I'm ready to pay higher transfer payments to the distribution companies than today if power outages in my household become less frequent." The respondents clearly rejected this statement. Only 12\% agreed whereas $80 \%$ disagreed (see Figure 6.4). Furthermore, it should be noted that $50 \%$ of respondents disagreed totally. Women and men had very similar views on higher payments. Although the share of undecided respondents was higher among women $(12 \%)$ than men $(5 \%)$. In terms of age those aged 18 to 29 were most willing to pay higher transfer payments. The older age groups were less eager to pay. According to another survey 28\% of respondents in Finland agreed and $66 \%$ disagreed with the statement "I'm willing to pay more for electricity than today to avoid power outages" (Pitkänen and Westinen, 2017, p. 13). The 


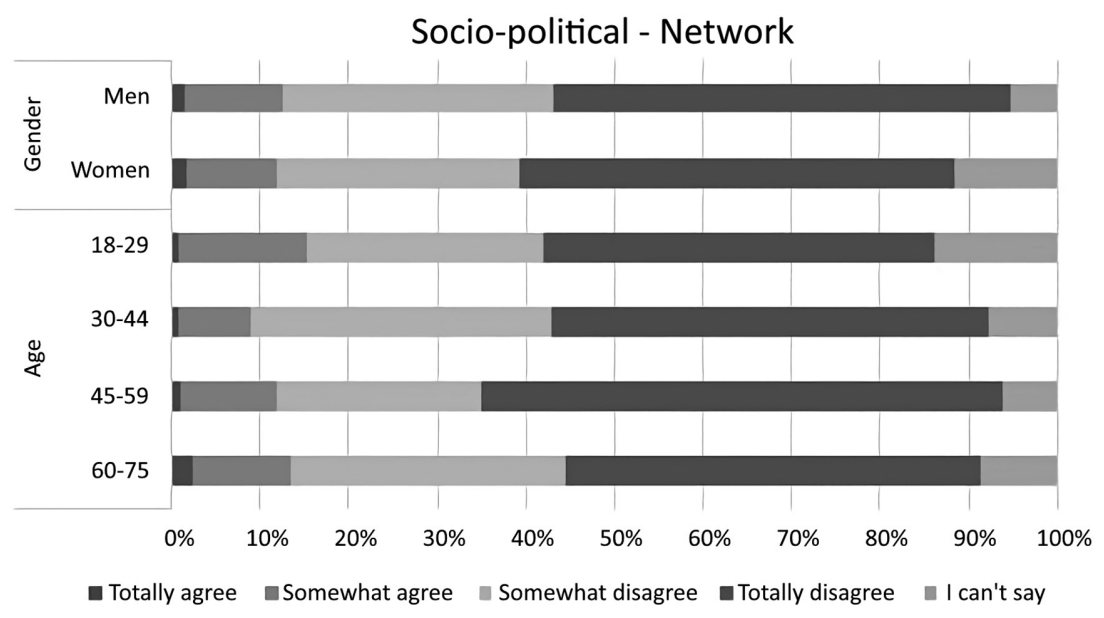

Figure 6.4 Respondents' attitudes to the statement concerning willingness to pay more for power transfer.

average interruption duration in disturbances in Finland is at present at a level of $1-1.5$ hours (h/customer, year), excluding years of extreme weather conditions. ${ }^{6}$

The statement concerning consumption on the socio-political dimension stated that "Personal emission quotas should be deployed." This was also rejected by the majority of respondents (62\%) (see Figure 6.5). One out of five (21\%) reported support for personal emissions quotas. Men were more critical than women. Of women almost one in four (23\%) agreed whereas less than one in five (19\%) men agreed. $70 \%$ of men disagreed (40\% disagreed totally) whereas $52 \%$ of women disagreed.

Deployment of personal emission quotas was most frequently supported by respondents educated in the humanities and arts (38\% agreed) whereas respondents having educational background in engineering (74\%) and agriculture and forestry $(70 \%)$ disagreed most frequently.

In terms of political affiliation, supporters of the Greens (43\%), the Left Alliance (30\%) and the Social Democratic Party (25\%) were most often in favor of personal emission quotas, whereas supporters of the Finns Party $(71 \%)$ and the National Coalition Party (71\%) most clearly disagreed with the statement on personal emission quotas.

\section{Community dimension}

According to our survey, $71 \%$ of respondents were in favor of increasing the share of wind power production, but if production were to be located in the vicinity of the respondents' homes, the acceptance decreased. However, support for wind power was still fairly high as $48 \%$ agreed and $45 \%$ disagreed with the statement (see Figure 6.6). Women were more tolerant than men. In terms of age groups, the 
Socio-political - Consumption

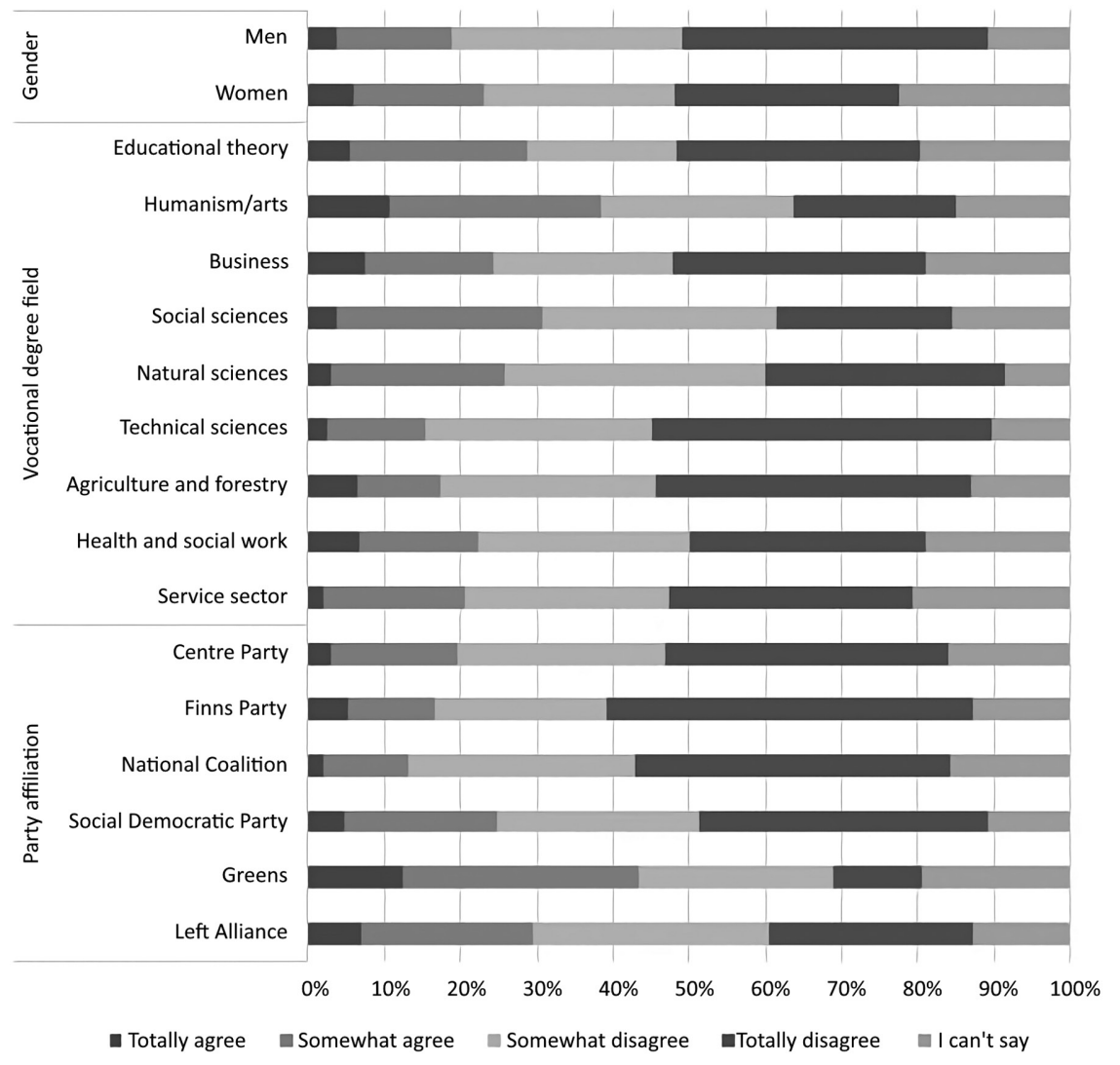

Figure 6.5 Respondents' attitudes on the statement "Personal emission quotas should be deployed."

youngest generation, i.e., those aged 18 to 29 , were the most tolerant of building wind power in the vicinity of their homes. The support for wind power decreased in the older age groups. In terms of political affiliation, supporters of the Greens (70\% agreed and 25\% disagreed) and the Left Alliance were most frequently in favor of building wind power. At the other extreme were supporters of the Finns Party (40\% agreed and 55\% disagreed).

The respondents were very satisfied with the reliability of electricity supply as more than nine out of ten (91\%) agreed with the statement "I'm satisfied with the current reliability of electricity supply to my household." In terms of age groups, the oldest group, i.e., those aged 60 to 75 , were most frequently satisfied $(94 \%$ agreed) (see Figure 6.7). Most dissatisfied were the respondents aged 30 to 44, but of these, too, $87 \%$ agreed and only $12 \%$ disagreed. Presumably the respondent's place of residence influenced opinions because the quality of electricity supply 


\section{Community - Production}

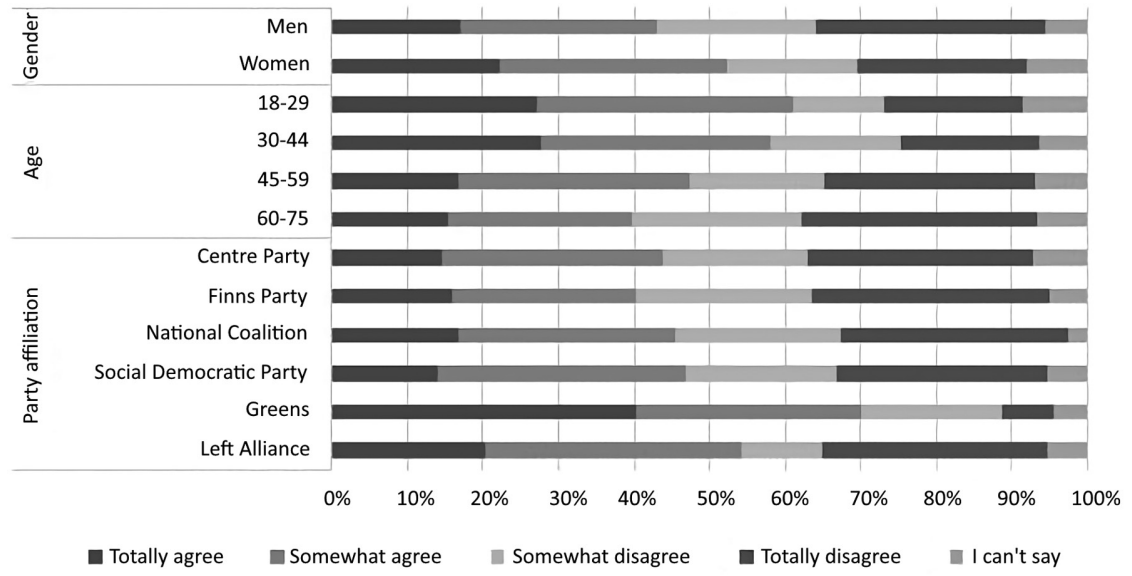

Figure 6.6 Respondents' attitudes on the statement "I accept building of wind power in the vicinity of my home."

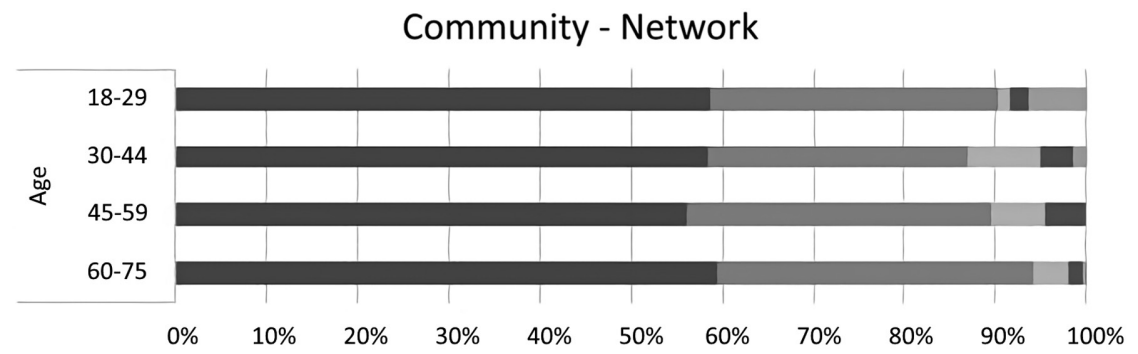

- Totally agree $\square$ Somewhat agree $\quad$ Somewhat disagree $\quad$ Totally disagree $\quad$ I can't say

Figure 6.7 Results of the survey on satisfaction with the current reliability of electricity supply at households.

in conurbations is better than in sparsely populated areas. The high satisfaction rates are also an explanation for unwillingness to pay more for transfer to the distribution companies for less frequent power outages in households.

The respondents gave only some support to achieving climate neutrality in their home municipalities by 2030 as $47 \%$ disagreed and $24 \%$ agreed with the statement on this. (see Figure 6.8). The fairly large share of undecided respondents $(30 \%)$ may reflect the novelty of the issue at the time of the survey. Men were more critical of this aim than women, and women (36\%) were more often undecided than men (24\%). In terms of age groups, the youngest $(50 \%)$, i.e., those aged 18 to 29 and the oldest (51\%), aged from 60 to 75, supported climate neutrality most frequently. $20 \%$ of the youngest and $22 \%$ of the oldest disagreed 


\section{Community - Consumption}

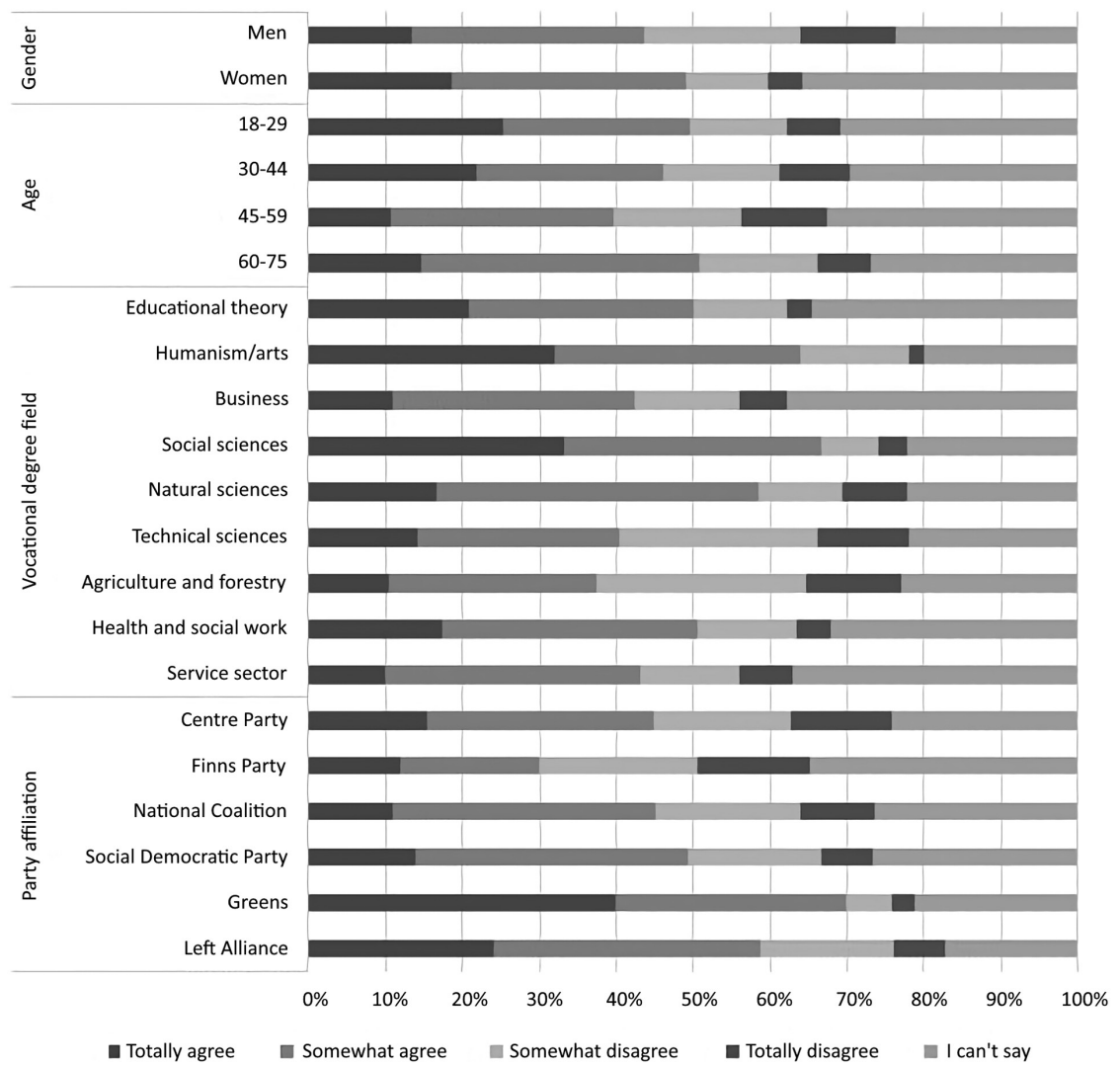

Figure 6.8 Respondents' attitudes on the statement "My home municipality will be climate neutral by 2030."

with the statement. In terms of field of education, those respondents having education in social sciences $(67 \%)$ and the humanities and arts $(64 \%)$ were most frequently in favor of being climate-neutral by 2030, whereas respondents with education in agriculture and forestry $(40 \%)$ most often disagreed with this aim. ${ }^{7}$ Supporters of the Greens (70\%) and the Left Alliance (59\%) were clearly in favor, whereas supporters of the Finns Party (35\%), the Centre Party (31\%) and the National Coalition Party (28\%) were most often against this statement.

\section{Market dimension}

As regards the market sector, the statement concerning production was as follows: "I'm ready to shift to dynamic pricing in which my electricity bill is based on hourly market prices" (see Figure 6.9). The respondents were rather skeptical 


\section{Matti Kojo et al.}

\section{Market - Production}

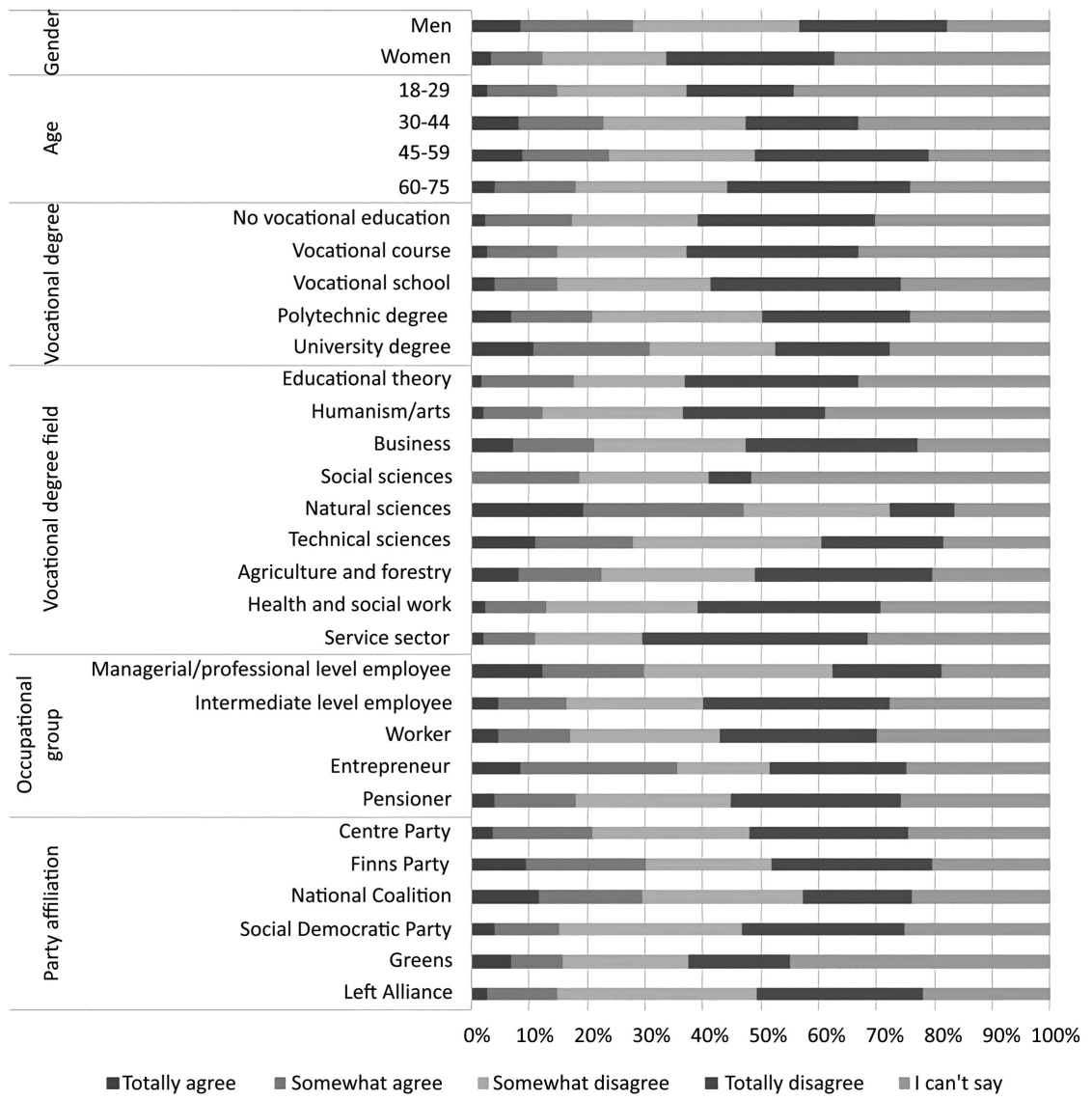

Figure 6.9 Respondents' attitudes to the statement "I'm ready to shift to dynamic pricing in which my electricity bill is based on hourly market prices."

towards shifting to dynamic pricing as $53 \%$ of the respondents disagreed and only $20 \%$ agreed with the statement. Over a quarter of respondents were undecided about it.

More men (28\%) agreed with the statement than women $(12 \%)$. Women were also much more uncertain as $37 \%$ of them could not state their opinion. In terms of age, the oldest group (age 60-75) was most skeptical towards shifting to dynamic pricing: $58 \%$ of them disagreed with the statement and only $18 \%$ were ready to shift to dynamic pricing. Younger age groups were more tolerant since almost every fourth of the age groups from 30-44 and 45-59 agreed with the statement. Yet the majority of them also rejected the statement. When looking at the education of the respondents those with a university degree were the most supportive of a shift to dynamic pricing in their electricity bills. $31 \%$ agreed and 
$41 \%$ disagreed with the statement as the corresponding numbers for respondents with short vocational education were $15 \%$ and $59 \%$. In addition, respondents with educational background in engineering or natural sciences were most frequently in favor of the statement. Up to $47 \%$ and $28 \%$ of them supported the statement when the corresponding figures for other respondents were decidedly lower. Managerial and professional employees stood out as the most supportive and pensioners as the most disapproving respondents regarding the statement. $30 \%$ of the supporters of the National Coalition Party and the Finns Party agreed and slightly less than half of them disagreed with the statement. Instead, the supporters of the Social Democratic Party and the Left Alliance rejected the statement most frequently as approximately $60 \%$ of them opposed the statement.

Moreover, on the network dimension the statement was "I'm ready to hand over control of some electricity intensive equipment to the service provider for reimbursement" (see Figure 6.10). Typically, this could be, for example, a water heater or comfort underfloor heating. This statement was strongly rejected by the respondents since $71 \%$ of them disagreed and only $29 \%$ agreed with it. The youngest age group, from 18-29, was most favorable towards handing over control of some electricity intensive equipment as $35 \%$ of them agreed with the statement. Most unwilling to hand over control was the oldest age group, of whom $35 \%$ totally disagreed with the statement. Again, managerial and professional employees were the most supportive respondents and pensioners the most disapproving respondents. $76 \%$ of the pensioners rejected and $24 \%$ supported the statement while $65 \%$ of the managerial and professional employees rejected and $35 \%$ supported the statement. The responses to these two abovementioned statements may also reflect a more general attitude towards market-based policy measures.

As regards the last dimension of social acceptance, consumption, the statement was as follows: "I favour the use of renewable energy in my household" (see

\section{Market - Network}

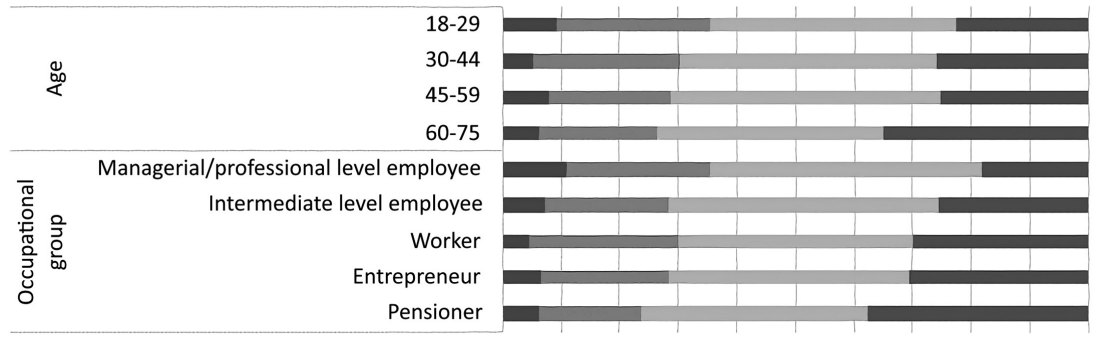

$\begin{array}{llllllllllll}0 \% & 10 \% & 20 \% & 30 \% & 40 \% & 50 \% & 60 \% & 70 \% & 80 \% & 90 \% & 100 \%\end{array}$

घ Totally agree $\quad$ Somewhat agree $\square$ Somewhat disagree $\quad$ Totally disagree

Figure 6.10 Respondents' attitudes on the statement "I'm ready to hand over the control of some electricity intensive equipment to the service provider for reimbursement." 


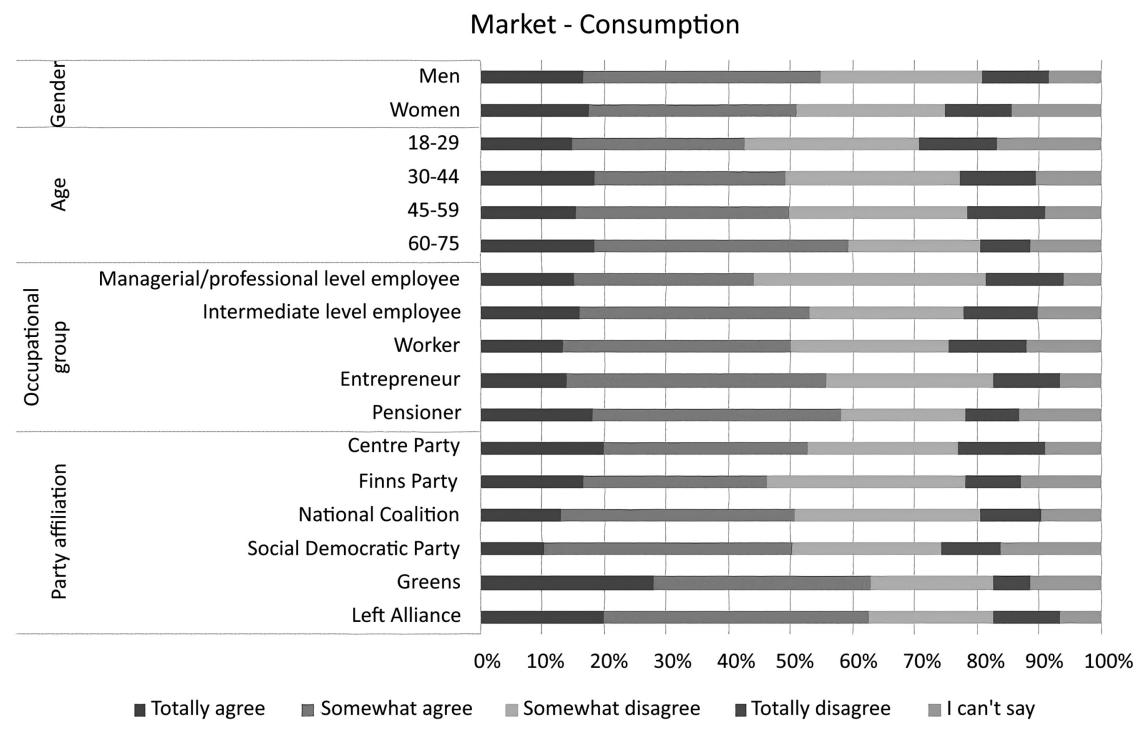

Figure 6.11 Respondents' attitudes on the use of renewable energy in their household.

Figure 6.11). This statement was more frequently supported by respondents than the market sector statements concerning production and network. Over $50 \%$ of all respondents agreed with this statement and slightly more than a third of them disagreed with the statement. The share of those who were undecided was $12 \%$. In terms of gender the views were quite similar, but men appeared to be slightly more frequently in agreement with the statement. The majority of all age groups agreed with the statement yet the oldest age group, those aged 60-75, was the most supportive. $59 \%$ of them favored the use of renewable energy in their households leaving only $29 \%$ of them to disagree with the statement. Pensioners were the most supportive occupational respondent group regarding this statement as $58 \%$ of them agreed and $29 \%$ disagreed with the statement.

Supporters of the Greens and the Left Alliance favored the use of renewable energy in their households most. The least supportive of this statement were the supporters of the Finns Party, the National Coalition Party and the Centre Party of Finland.

\section{Discussion}

The objective of the chapter was to study the social acceptability of the transition of the electric energy system in Finland. Conceptually the study relies on a two-dimensional differentiation of acceptability, acceptance and support where support embodies the behavioral dimension as opposed to mere attitudinal acceptance (see Dreyer et al., 2017; see Figure 6.1). The long-term realization of such active support would be an important asset for the implementation of 
the energy transition although the economic control of electricity use at household level is thought to be increasingly based on automation. Implementation of support can be monitored and scrutinized if there are statistics available on the subject. For instance, how many households have switched to dynamic pricing in electricity billing.

Social acceptability was ascertained by focusing on three dimensions of acceptability, namely the socio-political, community and market dimensions of the electric energy system, consisting of production, network and consumption sectors (see Table 6.1). On the basis of the survey each sector faces challenges on all dimensions of acceptability, which also stresses the importance of public communication and engagement in energy transition.

Earlier Bolwig et al. (2020, p. 11) noted that low social acceptance of two key technologies (onshore wind power and electricity transmission lines) "have important system-wide effects, notably distributional effects regarding electricity prices and revenues, effects on the installed capacity of different RE technologies and effects on the consumer costs of electricity" in the Nordic-Baltic energy region.

Our respondents' opinions regarding production were somewhat divided on all dimensions. At the policy level $42 \%$ of respondents supported the shift to entirely renewable energy production by 2030 , but $46 \%$ disagreed with the statement. ${ }^{8}$ It should be noted that electricity production in Finland is currently heavily dependent on nuclear power and in recent years increasing nuclear power generation has received support in surveys (Finnish Energy, 2019). Two new nuclear reactors with an expected operational lifetime of 60 years are under construction. Prematurely phasing out nuclear power production would entail costs, which were not mentioned in the statement. On the community dimension of production almost half of the respondents were willing to accept building wind power in the vicinity of their homes. Another challenge on the production side seems to be the adoption of dynamic pricing for households, i.e., a bill based on hourly market prices. More than half of respondents disagreed with this, but the share of those undecided was fairly high $(27 \%)$. However, this is somewhat in line with earlier reports (Fell et al., 2015). Similar to home automation, dynamic pricing was also supported. According to Eurelectric (2017, p. 4) approximately $10 \%$ of Finnish customers had chosen this tariff (i.e., about 340,000 customers). ${ }^{9}$ Thus, despite the Finnish legacy of centralized electricity production (see Varho et al., 2016) there are consumers who are potentially interested in being front runners in energy transition at the level of households, which also underlines the importance of both behavioral and attitudinal support instead of mere favorable attitude to the transition to an electric energy system.

The network sector seems to face challenges in both socio-political and market dimensions. The respondents are not willing to pay more for electricity transfer even if they would benefit by having less frequent power outages. Rising transfer payments have faced a lot of public criticism and media attention since 2013, when the new Electricity Market Act came into force. The Act required the construction of a weather-proof electricity distribution network which should 


\section{Matti Kojo et al.}

be available to all customers within a certain period of time to ensure continuity of supply. More recently the debate and policy measures have focused on the rationalization of transfer payments and success of regulation. The goal is also recorded in the current government program. In this sense, the lack of support for higher payments is no surprise.

However, this could open up an opportunity for the development of individual and collective self-consumption and even microgrids, particularly if such projects were perceived as locally driven (von Wirth et al., 2018). The desire to avoid higher transfer payments may also increase public interest in investments in decentralized electricity production systems at the level of households. At the same time, home automation needed for the development of demand response flexibility in households seemed to be a less attractive option for the majority of respondents even if reimbursement were offered. The advantages of large-scale deployment of home automation for the future electric energy system are perhaps still rather unfamiliar to the general public. Data protection issues were not measured in this survey but may explain the result at least in part (de Wildt et al., 2019). It should be noted that the majority (91\%) of the respondents stated that they were satisfied with the current reliability of electricity supply. Thus, interest in the development of the network is lacking among the general public. In terms of policymaking this means that the pressure to invest in building underground cabling for improved electricity distribution in the event of disturbances is not currently high. However, Lienert et al. (2015) note that acceptance of grid expansion is higher in the context of energy transition and that different types of expansions should be distinguished. Also, it remains to be seen how consumers react to the capacity-based network tariffs which are currently being introduced in Finland. At present three Finnish Distribution System Operators (DSO) have started to apply tariffs that include a demand charge, in addition to fixed and volumetric charges to some of their small customers. One DSO operates in the metropolitan area. It is likely that other DSOs will start to impose similar changes in their pricing in the near future (Lummi et al., 2019).

In the consumption sector respondents supported activities towards climate neutrality in their home municipalities but disagreed with the deployment of personal emission quotas. Thus, when personal commitment is required, the respondents become more reluctant. However, support for the use of renewables in households is high (i.e., $53 \%$ of respondents). In practice, the solutions of many households depend on the actors and decisions of the housing associations which manage the apartment buildings (Laakso and Lukkarinen in this volume). On the basis of the respondents' opinions, we share the view that there is potential for developing a decentralized energy system in Finland (Ruostetsaari, 2020). In more general terms, different opinions concerning different aspects of energy transition between population groups indicate potential barriers that may become an acceptability issue. On the other hand, the results also revealed topics where certain population groups have a greater interest in and perhaps even support adopting new energy applications and moving forward in energy transition. Such information on population groups helps to identify potential front runners 
and on the other hand to focus communication and stakeholder engagement activities on issues that may require more discussion with the affected parties. Therefore, the results show how the level of acceptability and support varies between population groups depending on the topic. This may help to understand how an acceptability issue calls for the identification of case-sensitive "publics" and their concerns in energy transition projects. Differentiation of acceptance among user groups becomes even more central in the case of the Citizen and Renewable Energy Communities that are being introduced in Finland following the EU's new Internal Electricity Market Directive (2019/944) (European Union, 2019b) and Renewable Energy Directive (European Union, 2018/2001). These initiatives require wider community acceptance and engagement than individual choices. On the other hand, a community-owned model has the potential to address many of the issues raised in this study (von Wirth et al., 2018).

\section{Conclusions}

Energy transition requires both attitudinal and behavioral support from the general public. Finland has notable technical conditions - such as smart metering equipment installed in almost every household - for energy transition, but as Finnish energy policy, and particularly production, has been based on centralized technical-economic solutions activating and engaging small consumers and individuals can be a blind spot - even an object of hostility regarding new renewable energy actors and policies (Varho et al., 2016, p. 36). In this respect, Finland should look at the policy approaches and measures adopted in other countries. If Finland aims at large-scale electrification of society in order to achieve decarbonization, the smart control of electricity loads in households will require new business and service concepts, automation and active support from individuals and consumers. Smart meters, which are indeed currently available, play an essential role, but Finland will also need more advanced and comprehensive automated systems having open and interoperable interfaces to run the whole flexibility market in almost real-time. More generally, the question is what policy instruments should be introduced to accelerate the energy transition (see Aalto, 2021).

One task to empower customer participation in the electricity market is to incorporate more widely into the national legislation the new Directive (EU) 2019/944 of the European Parliament and of the Council on common rules for the internal market for electricity. The new directive determines energy community as a new actor in the electrical energy market. The concept of energy community may activate customers and prosumers to participate in the electricity market and to offer flexible services. In this, housing associations, which are managed by professional real estate managers, play a key role in Finland. In terms of policy instruments, the development of management concepts and engagement campaigns in energy communities would be needed to raise the awareness of small consumers. Moreover, fixed-term regulatory sandboxes would encourage experimentation and examination of tariffs and incentives in energy communities. Better engagement of households and small consumers would also facilitate 
cost-efficient sector coupling between the building and transport sectors in the Finnish electricity system. In practice, this could mean, for example, the proliferation of load control and Vehicle-to-Home systems which would be a valuable asset for energy transition based on electrification.

\section{Acknowledgment}

The authors would like to thank Anna-Riikka Aarnio, Mika Kari, Hannele Holttinen, Pasi Toivanen and Kirsi Kotilainen for their contributions to the earlier version of the article. This work was funded by the Strategic Research Council at the Academy of Finland, project "Transition to a resource efficient and climate neutral electricity system" (EL-TRAN, project no 314319).

\section{Notes}

1 In developed countries, off-grid solutions are linked to norms of independence, selfsufficiency and environmental friendliness (Hojčková, Sandén and Ahlborg, 2018).

2 Renewable energy sources account for about $40 \%$ of energy end-consumption in Finland, the most important forms of renewable energy being bioenergy, hydropower, wind power and ground source heat pumps.

3 Respondents' address information was purchased from The Population Register Center on 1 July 2016 (Ruostetsaari, 2020).

4 For instance, in a choice experiment survey of demand side flexibility in Finnish households, conducted in October 2016, the response rate was 9.5\% (Ruokamo et al., 2018, p. 14). In a survey of Finns' images of a sustainable energy transition the response rate was $15.3 \%$. Data was collected in 2017 through an online questionnaire using a consumer panel (Vainio et al., 2019, p. 608).

5 Political affiliation of the respondents was inquired as follows: "If parliamentary elections were held now, which political party's candidate would you vote for?" Response options listed all the political parties represented in Parliament, "I would not vote at all," "I can't say" and "I don't want to disclose."

6 Looking more closely at winter storms, Janika in 2001 caused interruptions in electricity distribution for over 400,000 customers, storm Tapani (2011) for 300,000 customers and the latest winter storm, Aapeli, in 2019 for 120,000 customers. In these major disturbances customers had interruptions which continued over days or even weeks. (Seppälä and Järventausta, 2019).

7 Those having education in the humanities most often rely on the ability of science to solve the problems of halting climate change (Kiljunen 2019, 65-66).

8 It should be noted that no distinctions between the various forms of renewable energy are made in this statement. Wind, solar and biomass are all sources of renewable energy, but there can be notable differences, for example, in their respective GHG emissions. Therefore, in the context of this chapter no inferences on the acceptability of different forms of renewable energy can be made.

9 By February 2017 spot based pricing was available to residential consumers only in the Nordic, Estonian and Spanish electricity markets (Eurelectric, 2017, p. 3).

\section{References}

Aalto, P. (Ed.) (2021). Electrification: Accelerated Transition to Climate Neutrality. Cambridge: Academic Press. 
Batel, S. (2018). A critical discussion of research on the social acceptance of renewable energy generation and associated infrastructures and an agenda for the future. Journal of Environmental Policy \& Planning, 20(3), Abingdon: Taylor \& Francis, pp. 356-69.

Bergmans, A., Sundqvist, G., Kos, D. and Simmons, P. (2014). The participatory turn in radioactive waste management: Deliberation and the social-technical divide. Journal of Risk Research, Abingdon: Routledge, 18 (3), pp. 347-363 . DOI:10.1080/13669877. 2014.971335

Bolwig, S., Bolkesjø, T. F., Klitkou, A., Lund, P., Bergaentzlé, C., Borch, K., Olsen, O. J., Kirkerud, J. G., Chen, Y., Gunkel, P. A. and Skytte, K. (2020). Climate-friendly but socially rejected energy-transition pathways: The integration of techno -economic and socio-technical approaches in the Nordic-Baltic region. Energy Research and Social Science, 67, Amsterdam: Elsevier, p. 101559. DOI:10.1016/j.erss.2020.101559

Devine-Wright, P., Batel, S., Aas, O., Sovacool, B., LaBelle, M. C. and Ruud, A. (2017). A conceptual framework for understanding the social acceptance of energy infrastructure: Insights from energy storage. Energy Policy, 107, Amsterdam: Elsevier, pp. 27-31. DOI:10.1016/j.enpol.2017.04.020

Dreyer, S. J., Polis, H. J. and Jenkins, L. D. (2017). Changing tides: Acceptability, support, and perceptions of tidal energy in the United States. Energy Research Eु Social Science, 29, Amsterdam: Elsevier, pp. 72-83. DOI:10.1016/j.erss.2017.04.013

Energy Authority. (2020). Aurinkosähkön tuotantokapasiteetti jatkoi kasvuaan vuonna 2019 - vuosikasvua 64 prosenttia. Press release on 18 June. Available at: https:// energiavirasto.fi/en/-/aurinkosahkon-tuotantokapasiteetti-jatkoi-kasvuaan-vuonna -2019-vuosikasvua-64-prosenttia [Accessed 14 December 2020].

Eurelectric. (2017). Dynamic pricing in electricity supply. A EURELECTRIC position paper. February 2017. Available at: http://www.eemg-mediators.eu/downloads/ dynamic_pricing_in_electricity_supply-2017-2520-0003-01-e.pdf [Accessed 3 May 2021].

European Union. (2018/2001). Directive (EU) 2018/2001 of the European Parliament and of the Council of 11 December 2018 on the promotion of the use of energy from renewable sources. Available at: http://data.europa.eu/eli/dir/2018/2001/oj [Accessed 3 May 2021].

European Union. (2019a). Clean energy for all Europeans package. Available at: https:// ec.europa.eu/energy/topics/energy-strategy/clean-energy-all-europeans_en [Accessed 3 May 2021].

European Union. (2019b). Directive 2019/944 on common rules for the internal market for electricity. European Union, Official Journal of the European Union.

Fell, M. J., Shipworth, D., Huebner, G. M. and Elwell, C. A. (2015). Public acceptability of domestic demand-side response in Great Britain: The role of automation and direct load control. Energy Research EF Social Science, 9, Amsterdam: Elsevier, pp. 72-84. DOI:10.1016/j.erss.2015.08.023

Finnish Energy. (2019). Suomalaisten energia-asenteet. Available at: https://energia.fi/ meista/tutkimus/energia-asenteet [Accessed 14 December 2020].

Flynn, R. (2007). Risk and the public acceptance of new technologies. In: R. Flynn and P. Bellaby, eds., Risk and the Public Acceptance of New Technologies. Basingstoke: Palgrave MacMillan, pp. 1-23.

Geels, F. W., Berkhout, F. and van Vuuren, D. P. (2016). Bridging analytical approaches for low-carbon transitions. Nature Climate Change, 6, London: Nature Research, pp. 576-83. DOI:10.1038/nclimate2980 


\section{Matti Kojo et al.}

Gupta, N., Fischer, A. R. H. and Frewer, L. J. (2012). Socio-psychological determinants of public acceptance of technologies: A review. Public Understanding of Science, 21, Thousand Oaks: SAGE Publishing, p. 782. DOI:10.1177/0963662510392485

Haukkala, T. (2018). A struggle for change - The formation of a green-transition advocacy coalition in Finland. Environmental Innovation and Societal Transformation, 27, Amsterdam: Elsevier, pp. 146-56. DOI:10.1016/j.eist.2017.12.001

Hildén, M. and Kivimaa, P. (2020). Energy governance in Finland. In: M. Knodt and J. Kemmerzell, eds., Handbook of Energy Governance in Europe. Cham: Springer, pp. 1-28. DOI:10.1007/978-3-319-73526-9_9-1.

Hojčková, K., Sandén, B. and Ahlborg, H. (2018). Three electricity futures: Monitoring the emergence of alternative system architectures. Futures, 98, Amsterdam: Elsevier, pp. 72-89. DOI:10.1016/j.futures.2017.12.004

Horbaty, R., Huber, S. and Ellis, G. (2012). Large-scale wind deployment, social acceptance. Wiley Interdisciplinary Reviews: Energy and Environment, 1(2), Hoboken: John Wiley \& Sons, pp. 194-205. DOI:10.1002/wene.9

Huijts, N. M. A., Midden, C. J. H. and Meijnders, A. L. (2007). Social acceptance of carbon dioxide storage. Energy Policy, 35(5), Amsterdam: Elsevier, pp. 2780-9. DOI:10.1016/j.enpol.2006.12.007

Järvelä, M., Kortetmäki, T., Huttunen, S., Turunen, A. and Tossavainen, S. (2020). Ilmastotoimien sosiaalinen hyväksyttävyys. Suomen ilmastopaneeli. Raportti 1/2020. Available at: https://www.ilmastopaneeli.fi/aineistot-ja-raportit/\#ilmastotoimien -sosiaalinen-hyvaksyttavyys-2020 [Accessed 5 June 2020].

Järventausta, P. (2015). Smart grids with large scale implementation of automatic meter reading - Experiences from Finland. In: E. Dahlquist, A. Conejo and J. Yan Eds., The Handbook of Clean Energy Systems. Hoboken: John Wiley \& Sons. DOI:10.1002/9781118991978.hces129

Järventausta, P., Verho, P., Partanen, J. and Kronman, D. (2011). Finnish smart grids - A migration from version one to the next generation. In: Proceedings of the 21 st International Conference on Electricity Distribution, Frankfurt, CIRED, p. 4.

Kainiemi, L., Karhunmaa, K. and Eloneva, S. (2020). Renovation realities: Actors, institutional work and the struggle to transform Finnish energy policy. Energy Research EF Social Science, 70, Amsterdam: Elsevier, p. 101778. DOI:10.1016/j. erss.2020.101778

Kardooni, R., Yusoff, S. B. and Kari, F. B. (2016). Renewable energy technology acceptance in Peninsular Malaysia. Energy Policy, 88, Amsterdam: Elsevier, pp. 1-10. DOI:10.1016/j.enpol.2015.10.005

Kasperson, R. E. and Ram, B. J. (2013). The public acceptance of new energy technologies. Daedalus, 142(1), Cambridge: MIT Press, pp. 90-6. DOI:10.1162/DAED_a_00187

Kiljunen, P. (2019). Tiedebarometri 2019. Tutkimus suomalaisten suhtautumisesta tieteeseenja tieteellis-tekniseen kehitykseen. [Helsinki] Tieteen tiedotus ry. Yhdyskuntatutkimus Oy. Available at: http://www.tieteentiedotus.fi/tiedebarometri.html [Accessed 23 April 2020].

Kotilainen, K. (2020). Perspectives on the Prosumer Role in the Sustainable Energy System. Tampere University Dissertations 259. Tampere: Tampere University, URN:ISBN:978-952-03-1576-4

Kotilainen, K., Valta, J., Saari, U. A., Kojo, M. and Ruostetsaari, I. (2021). From energy consumers to prosumers - How do policies influence the transition? In: P. Aalto, ed., Electrification: Accelerated Transition to Climate Neutrality, pp. 197-215. Cambridge: Academic Press. 
Krick, E. (2018). Ensuring social acceptance of the energy transition. The German government's 'consensus management' strategy. Journal of Environmental Policy EF Planning, 20(1), Abingdon: Taylor \& Francis, pp. 64-80. DOI:10.1080/15239 08X.2017.1319264

Leiren, M. D., Aakre, S., Linnerud, K., Julsrud, T. E., Di Nucci, M.-R. and Krug, M. (2020). Community acceptance of wind energy developments: Experience from wind energy scarce regions in Europe. Sustainability, 12(5), Basel: MDPI, p. 1754. DOI:10.3390/ su12051754

Lennon, B., Dunphy, N. P. and Sanvicente, E. (2019). Community acceptability and the energy transition: A citizens' perspective. Energy, Sustainability and Society, 9(35), p. 9807, Basingstoke: Springer Nature. DOI:10.1186/s13705-019-0218-z

Lienert, P., Suetterlin, B. and Siegrist, M. (2015). Public acceptance of the expansion and modification of high-voltage power lines in the context of the energy transition. Energy Policy, 87, Amsterdam: Elsevier, pp. 573-83. DOI:10.1016/j.enpol.2015.09.023

Lummi, K., Mutanen, A. and Järventausta, P. (2019). Upcoming changes in distribution network tariffs - Potential harmonization needs for demand charges. In: Proceedings of 25th International Conference on Electricity Distribution, Paper no 1680. Madrid, CIRED, p. 5. DOI:10.34890/741

MEAE. (2017). Government Report on the National Energy and Climate Strategy for 2030. Publications of the Ministry of Economic Affairs and Employment 12/2017. URN:ISBN:978-952-327-199-9.

Pahkala, T., Uimonen, H. and Väre, V. (2018). Flexible and Customer-Centred Electricity System. Final Report of the Smart Grid Working Group. Publications of the Ministry of Economic Affairs and Employment 39/2018, Finland. URN:ISBN:978-952-327-352-8.

Penttinen, S.-L., Aalto, P. and Haukkala, T. (2020). EU Electricity Market Reform and the Adoption of the Clean Energy Package Addressing System Flexibility. EL-TRAN Policy Brief 1/2020. Tampere: Tampere University. URN:ISBN:978-952-03-1508-5.

Pitkänen, V. and Westinen, J. (2017). Suomalaisten asenteet ja aktiivisuus energia-asioissa. Helsinki: e2 Think tank. Available at: https://www.e2.fi/hankkeet-ja -julkaisut/julk aisut/suomalaisten-asenteet-ja-aktiivisuus-energia-asioissa [Accessed 11 May 2021].

Pöyry Management Consulting. (2017). Minimum Functionalities of Next-Generation Smart Electricity Meters. December 2017. Report for the Smart Grid Working Group of the Ministry of Economic Affairs and Employment (MEAE). Available at: https://tem .fi/documents/1410877/3481825/AMR+2.0 + loppuraportti+15.12.2017/6a2df7e6-a 963-40c0-b4d8-d2533fbca488/ AMR+2.0+loppuraportti+15.12.2017.pdf [Accessed 13 January 2021].

Ruokamo, E., Kopsakangas-Savolainen, M., Meriläinen, T. and Svento, R. (2019). Towards flexible energy demand - Preferences for dynamic contracts, services and emissions reductions. Energy Economics, 84, Amsterdam: Elsevier, p. 104522. DOI:10.1016/j.eneco.2019.104522

Ruostetsaari, I. (2020). From consumers to energy citizens: Finns' readiness for demand response and prosumerism in energy policy making. International Journal of Energy Sector Management. Bingley: Emerald Publishing. DOI:10.1108/IJSM-11-2019-0001

Seppälä, J. and Järventausta, P. (2019). Steering effect of distribution regulation in Finland. In: Proceedings of 25th International Conference on Electricity Distribution, Madrid: CIRED. Paper no 1029. DOI:10.34890/477

Sovacool, B. (2017). Contestation, contingency, and justice in the Nordic lowcarbon energy transition. Energy Policy, 102 ${ }^{\text {nd }}$ ed, Amsterdam: Elsevier, pp. 569-82. DOI:10.1016/j.enpol.2016.12.045 


\section{Matti Kojo et al.}

Statistics Finland. (2019). Energy year 2018. Figure electricity supply 1970-2018. Available at: https:/pxhopea2.stat.fi/sahkoiset_julkaisut/energia2019/html/ engl0002 .htm [Accessed 3 September 2020].

Sütterlin, B. and Siegrist, M. (2017). Public acceptance of renewable energy technologies from an abstract versus concrete perspective and the positive imagery of solar power. Energy Policy, 106, Amsterdam: Elsevier, pp. 356-66. DOI:10.1016/j.enpol.2017.03.061

TNS Energiabarometri Q1. (2016). Energian toimitusvarmuus rakentaa luottamusta energia -alaan. Newsletter [online]. Helsinki: TNS Gallup. Kantar. Available at: https://www.kantar.fi/uutiset/energian-toimitusvarmuus-rakentaa-luottamusta-energia -alaan [Accessed 3 May 2021].

Toivanen, P., Lehtonen, P., Aalto, P., Björkqvist, T., Järventausta, P., Kilpeläinen, S., Kojo, M. and Mylläri, F. (2017). The 2030 energy system of Finland as envisioned by expert stakeholders. Energy Strategy Reviews, 18, Amsterdam: Elsevier, pp. 150-6. DOI:10.1016/j.esr.2017.09.007

Umit, R., Poortinga, W., Jokinen, P. and Pohjolainen, P. (2019). The role of income in energy efficiency and curtailment behaviours: Findings from 22 European countries. Energy Research EF Social Science, 53, Amsterdam: Elsevier, pp. 206-14. DOI:10.1016/j. erss.2019.02.025

Upham, P., Oltra, C. and Boso, À. (2015). Social acceptance of energy technologies, infrastructures and applications: Towards a general cross-paradigmatic analytical framework. Energy Research EF Social Science, 8, Amsterdam: Elsevier, pp. 100-12.

Vainio, A., Varho, V., Tapio, T., Pulkka, A. and Paloniemi, R. (2019). Citizens' images of a sustainable energy transition. Energy, 183, Amsterdam: Elsevier, pp. 606-16. DOI:10.1016/j.energy.2019.06.134

van Alphen, K., van Voorst tot Voorst, Q., Hekkert, M. P. and Smits, R. (2007). Societal acceptance of carbon capture and storage technologies. Energy Policy, 35, Amsterdam: Elsevier, pp. 4368-80.

Varho, V., Rikkonen, P. and Rasi, S. (2016). Futures of distributed small-scale renewable energy in Finland - A Delphi study of the opportunities and obstacles up to 2025. Technological Forecasting Eु Social Change, 104, Amsterdam: Elsevier, pp. 30-7. DOI:10.1016/j.techfore.2015.12.001.

de Wildt, T. E., Chappin, E. J. L., van de Kaa, G., Herder, P. M. and van de Poel, I. R. (2019). Conflicting values in the smart electricity grid a comprehensive overview. Renewable and Sustainable Energy Reviews, 111, Amsterdam: Elsevier, pp. 184-96.

von Wirth, T., Gislason, L. and Seidl, R. (2018). Distributed energy systems on a neighborhood scale: Reviewing drivers of and barriers to social acceptance. Renewable and Sustainable Energy Reviews, 82, Amsterdam: Elsevier, pp. 2618-28. DOI:10.1016/j. rser.2017.09.086

Wolfe, A. K., Bjornstad, D. J., Russell, M. and Kerchner, N. D. (2002). A framework for analyzing dialogues over the acceptability of controversial technologies. Science, Technology $\mathcal{E}$ Human Values, 27(1), Thousand Oaks: SAGE Publishing, pp. 134-59. DOI:10.1177/016224390202700106

Wolsink, M. (2012). Wind power: Basic challenge concerning social acceptance. In: R. A. Meyers, ed., Encyclopedia of Sustainability Science and Technology, Volume 17. New York: Springer, pp. 12218-54. DOI: 10.1007/SpringerReference_301324

Wüstenhagen, R., Wolsink, M. and Bürer, M. J. (2007). Social acceptance of renewable energy innovation: An introduction to the concept. Energy Policy, 35, Amsterdam: Elsevier, pp. 2683-91. DOI:10.1016/j.enpol.2006.12.001 